\title{
BAKTI SOSIAL PEMBERSIHAN LINGKUNGAN MASJID JAMI' AT- TAQWA ONEKORE DALAM RANGKA PANCA WINDU UNIVERSITAS FLORES KE-40 TAHUN 2020
}

\author{
Fatma Wati1 ${ }^{*}$, Ariswan Usman Aje ${ }^{2}$, Marsel Nande ${ }^{3}$, Elias Beda \\ 1,2,34Universitas Flores, Ende, Indonesia \\ *Penulis Koresponsensi, email: fatmawatiuniflor@gmail.com
}

Article History

Received:01/11/2020

Revised:8/11/2020

Accepted:15/11/2020

\begin{abstract}
The implementation of this community service activity is motivated by a global issue that is currently developing, namely the spread of the COVID 19 virus. The spread of the virus, which also occurs in Ende district, has awakened various parties to implement a clean lifestyle, make efforts to prevent and break the chain of spread of the COVID 19 virus. One of these efforts is realized through this community service activity, namely by cleaning, socializing and spraying disinfectants in public areas. One of the areas that became the target of this dedication was the Jami At'Taqwa Onekore Ende Mosque. To achieve the goal of this Community Service activity is carried out through several approaches, including; 1) Participatory Rural Appraisal (PRA) Model which emphasizes community involvement in all activities starting from planning, implementing and evaluating activity programs, 2) Participatory Technological Development Model which utilizes appropriate technology based on local knowledge and wisdom, 3) Model Community development is an approach that involves the community directly as the subject and object of implementation of community service activities, 4) Persuasive, namely an approach that is appeal and support without coercion for the community to take an active role in this activity, 5) Educative, namely the socialization, training and mentoring as a means of transferring knowledge and education. The results of the Social Service Activities for cleaning the environment of the Jami 'At-Taqwa Onekore Mosque can run well in accordance with the activity plan, namely cleaning the mosque environment, cleaning irrigation ditches, transporting garbage and spraying disinfectants. This is shown from the following conclusions; 1) All residents become enthusiastic training participants and have a good commitment to all the programs discussed before the activity for the sake of creating a sense of security and peace in worship in the midst of the Covid 19 pandemic, 2) There has been an increased understanding of the knowledge of the Covid 19 outbreak and how to maintain security self in minimizing outbreaks. Namely by means of 3M (Keeping Distance, Washing Hands and Wearing Masks), 3) A place of worship that is clean, safe and comfortable and has a safe distance limit mark in worship.
\end{abstract}

Keywords: Social Service, Covid-19, Environment, Mosque At'Taqwa

\begin{abstract}
Abstrak. Pelaksanaan kegiatan pengabdian masyarakat ini dilatarbelakangi oleh isu global yang berkembang saat ini yakni penyebaran virus COVID 19. Penyebaran virus yang juga terjadi di kabupaten Ende ini, telah menyadarkan berbagai pihak untuk memberlakukan pola hidup bersih, melakukan upaya pencegahan dan memutus matarantai penyebaran virus COVID 19. Salah satu upaya tersebut diwujudkan melalui kegiatan pengabdian masyarakat ini, yakni dengan melakukan pembersihan, sosialisasi dan penyemproten disinfektan di area umum. Salah satu area yang menjadi sasaran pengabdian ini adalah di Masjid Jami At'Taqwa Onekore Ende. Untuk mencapai tujuan kegiatan Pengabdian ini dilakukan melalui beberapa pendekatan, antara lain; 1) Model Participatory Rural Appraisal (PRA) yang menekankan keterlibatan masayarakat dalam keseluruhan kegiatan mulai dari perencanaan, pelaksanaan dan evaluasi program kegiatan, 2) Model Participatory Technologi Development yang memanfaatkan teknologi tepat guna yang berbasis pada ilmu pengetahuan dan kearifan budaya lokal, 3) Model Community development yaitu pendekatan yang melibatkan masyarakat secara langsung sebagai subjek dan objek pelaksanaan kegiatan pengabdian kepada masyarakat, 4) Persuasif yaitu pendekatan yang bersifat himbauan dan dukungan tanpa unsur paksaan bagi masyarakat untuk berperan aktif dalam kegiatan ini, 5) Edukatif yaitu pendekatan sosialisasi, pelatihan dan pendampingan sebagai sarana transfer ilmu pengatahuan dan pendidikan. Adapun hasil Kegiatan Bakti Sosial pembersihan lingkungan Masjid Jami' At-Taqwa Onekore dapat berjalan dengan baik sesuai dengan rencana kegiatan yakni pembersihan lingkungan Masjid, pembersihan selokan irigasi, pengangkutan sampah dan penyemprotan disenfektan. Hal tersebut ditunjukan dari kesimpulan berikut ini; 1)Semua warga menjadi peserta pelatihan antusias dan memiliki komitmen yang baik untuk semua program yang telah didiskusikan sebelum kegiatan demi terwujudnya rasa aman dan tentram dalam beribadah di tengah pandemic Covid 19, 2) Telah ada peningkatan pemahaman mengenai pengetahuan wabah Covid 19 dan bagaimana menjaga kemanan diri dalam meminimalisir terjangkitnya. Yakni dengan cara 3M (Menjaga Jarak, Mencuci Tangan dan Memakai Masker), 3) Tempat ibadah yang bersih, aman dan nyaman serta memiliki tanda batas jarak aman dalam beribadah.
\end{abstract}

Kata Kunci: Bakti Sosial, Covid-19, Lingkungan, Masjid Jami’ At-Taqwa

How to Cite: Wati, F., Aje, A. U., Nande, M., \& Beda, E. (2020). BAKTI SOSIAL PEMBERSIHAN LINGKUNGAN MASJID JAMI' ATTAQWA ONEKORE DALAM RANGKA PANCA WINDU UNIVERSITAS FLORES KE-40 TAHUN 2020. Mitra Mahajana: Jurnal Pengabdian Masyarakat, 1(1), 11-19. https://doi.org/10.37478/mahajana.v1i1.713 


\section{PENDAHULUAN}

\subsection{Analisis Situasi}

Dalam kurun waktu1 tahun ini, dunia dilanda dengan virus yang lebih kita kenal dengan Covid 19. Sejak WHO mengeluarkan deklarasi yang mengatakan dengan resmi bahwa virus Corona dengan nama ilmiahnya COVID-19 adalah pandemi global, maka banyak dari negara dengan penderita pandemi ini telah mengambil tindakan demi menyelamatkan warga negaranya. Cara penyeberan dan penularan virus dengan cepat dan telah menyebar hampir ke seluruh negara, termasuk Indonesia. Beberapa negara di luar negeri menerapkan kebijakan untuk memberlakukan lockdown dalam rangka mencegah penyebaran virus Corona.

Di Indonesia, pemerintah memberlakukan yang namanya PSBB yang tertuang dalam PP nomor 21 tahun 2020 tentang Pembatasan Sosial Bersekala Besar Dalam Rangka Percepatan Penanganan Covid 19. Oleh karena itu, segala bentuk kegiatan dibatasi terutama dalam beribadah. Pandemi itu membuat semua tempat ibadah untuk sementara ditutup, karena tidak diperbolehkan untuk berkumpul demi memutus rantai penyebaran covid 19.

Kota Ende sebuah kabupaten di pulau Flores, Provinsi Nusa Tenggara Timur. dengan luas kabupaten 2.067,75 $\mathrm{KM}^{2}$. Lingkungan Alam dan masyarakat Ende yang Plural sangat patut di contoh untuk berbagai daerah lain, karena sikap saling menghormati dan menghargai sesama antar umat beragama sangat tinggi. Covid 19 juga turut melanda Kabupaten ini, maka semua aktivitas beribadah baik itu di masjid, gereja dan Pura beberapa waktu yang lalu juga tidak diperbolehkan. Oleh karena Ende sekarang masuk dalam zona Hijau maka, aktivitas beribadah pun sudah mulai di perbolehkan dengan tetap mematuhi protocol kesehatan. Apalagi dalam masa Pandemi seperti saat ini, dimana kebersihan diri, lingkungan sekitar termasuk kebersihan rumah-rumah ibadah menjadi prioritas penting dalam upaya menangkal dan mencegah penyebaran virus Covid-19.

Masjid Jami' At-Taqwa Onekore merupakan salah satu Masjid Jami' yang ada di kota Ende. Masjid Jami' kebanggaan masyarakat Kelurahan Onekore dan sekitarnya ini dibangun pada tahun 1963 dan menempati posisi strategis yakni tepat berada di simpang tiga ruas jalan utama, yakni jalan Wirajaya, jalan Diponegoro dan jalan Nuamuri. Masjid Jami' At-Taqwa Onekore lebih dikenal dengan sebutan Masjid Papel atau Patung Pelajar karena terletak persis berhadapan dengan patung pelajar sebagai ikon kota Ende yakni kota pelajar. Jarak Antara Universitas Flores dengan Lokasi kegiatan adalah 2,5 KM, seperti gambar 1 dibawah ini.



Gambar 1. Jarak Lokasi Mitra Pengabdian 
Kebersihan adalah sebagian dari iman, demikian agama mengajarkan. Sebagai salah satu Masjid Jami' yang aktif digunakan oleh masyarakat kelurahan Onekore dan sekitarnya, Masjid Papel perlu tetap dijaga kebersihannya, baik dalam ruang sholat, area wudhu, kamar mandi, maupun di pekarangan Masjid. Karenanya kebersihan lingkungan Masjid dan perangkatperangkat yang digunakan tetap selalu diperhatikan oleh para pengurus Masjid At-Taqwa maupun oleh masyarakat dan jama'ah Masjid itu sendiri.

\subsection{Permasalahan Sasaran Pengabdian}

Masjid Jami' At-Taqwa Onekore atau Masjid Papel yang berlokasi di ruas utama jalan Wirajaya dan letaknya berdampingan dengan kompleks pendidikan dan perumahan warga. Dengan demikian lokasi Masjid menjadi sangat strategis bagi jama'ah Masjid maupun bagi masyarakat kota Ende yang hendak menunaikan sholat Jumad maupun sholat fardhu. Banyaknya jamaah yang berkunjung ke Masjid menjadikan Masjid rentan terhadap penyebaran virus dan bakteri apabila tidak dibersihkan secara berkala. Apalagi dimasa Covid 19 ini, penyebaran virus nya sangat mudah sekali ditularkan. Area Masjid maupun perangkatperangkat sholat dan perangkat bersuci misalnya sajadah, koleksi mukenah, sarung dan peci, area mimbar, ruangan Imam Masjid, sound system, area wudhu maupun kamar mandi merupakan benda-benda dan area yang bersentuhan langsung dengan aktifitas Imam Masjid dan jama'ah setiap hari.

Tabel 1. Prioritas Permasalahan yang disepakati bersama dengan Kelompok Mitra

\begin{tabular}{ccl}
\hline No & \multicolumn{1}{c}{ Bidang } & \multicolumn{1}{c}{ Prioritas Permasalahan } \\
$\mathbf{1}$ & Penguatan SDM & Selama Pandemi perangkat yang ada dalam Masjid Jami' At-Taqwa Onekore atau \\
& (Kebersihan) & Masjid Papel belum pernah di bersihkan \\
& & Area Lingkungan sekitar Masjid dan Selokan belum dibersihakan \\
& & Belum diberlakukan mencuci tangan ketika masuk area Masjid \\
\hline $\mathbf{2}$ & Pendidikan (Mengenai & Belum pernah mendapatkan pengetahuan tentang bagaimana menjaga jarak \\
& Covid 19) & dalam melakukan ibadah \\
& & Belum di buatnya batas-batas dalam Masjid untuk melaksanakan \\
& & \\
& & \\
& & Bbadah \\
& &
\end{tabular}

\section{METODE PELAKSANAAN}

Tergerak dengan niat yang sama, Universitas Flores yang pada tahun 2020 ini memasuki usia Panca Windu ke 40 tahun berinisiatif mengadakan kegiatan bakti sosial pembersihan lingkungan rumah-rumah ibadah sebagai bentuk kegiatan pengabdian kepada masyarakat. Terdapat setidaknya tujuh bentuk pengabdian kepada masyarakat, diantaranya adalah kegiatan pelayanan kepada masyarakat. Kegiatan pelayanan masyarakat dapat diterapkan dalam berbagai aspek yang berkaitan langsung dengan kepentingan masyarakat. Salah satu kegiatan yang tidak dapat lepas dari kehidupan masyarakat adalah ibadah (Riduan ,2016)

Rumah ibadah yang menjadi sasaran dalam kegiatan bakti sosial ini adalah Masjid Jami' At-Taqwa Onekore atau Masjid Papel. Pembersihan yang dilakukan juga merupakan upaya Universitas Flores turut serta dalam mencegah dan menangkal penyebaran virus Covid-19 dengan tetap memperhatikan dan mematuhi protokol kesehatan. Selain membersihkan sampah dan selokan irigasi di sekitar Masjid, tim kerja juga melakukan penyemprotan disenfektan ke seluruh bagian dalam dan luar area Masjid. Untuk mencapai tujuan kegiatan Pengabdian ini dilakukan melalui beberapa pendekatan, antara lain:

1. Model Participatory Rural Appraisal (PRA) yang menekankan keterlibatan masayarakat dalam keseluruhan kegiatan mulai dari perencanaan, pelaksanaan dan evaluasi program kegiatan

2. Model Participatory Technologi Development yang memanfaatkan teknologi tepat guna yang berbasasi pada ilmu pengetahuan dan kearifan budaya local 
3. Model Community development yaitu pendekatan yang melibatkan masyarakat secara langsung sebagai subjek dan objek pelaksanaan kegiatan pengabdian kepada masyarakat

4. Persuasif yaitu pendekatan yang bersifat himbauan dan dukungan tanpa unsur paksaan bagi masyarakat untuk berperan aktif dalam kegiatan ini

5. Edukatif yaitu pendekatan sosialisasi, pelatihan dan pendampingan sebagai sarana transfer ilu pengatahuan dan pendidikan untuk pemberdayaan masyarakat.

Secara teknis, tahap pelaksanaan kegiatan pengabdian sebagai berikut:

\section{a. Tahap Persiapan Awal dengan dengan Based Line Survey}

Pada tahap persiapan ini dilakukan untuk menginventarisasi adanya perubahan kondisi masyarakat sehingga desain kegiatan yang telah dilakukan dapat memeberikan solusi yang maksimal bagi permasalahan mitra. Selain itu di tahap awal ini juga akan dilakukan sosialisasi program secara lebih luas.

\section{b. Pelaksanaan Kegiatan}

Pelaksanaan kegiatan meliputi kegiatan Pemberian pengetahuan mengenai Covid 19 dan Pentingnya meningkatkan kebersihan lingkungan serta menjaga jarak dan Memakai Masker.

\section{c. Evaluasi dan monitoring Kegiatan}

Evaluasi dan monitoring kegiatan dilakukan secara periodik dengan melibatkan anggota pelaksana dan tokoh masayarakat setempat. Secara rincinnya bidang, masalah, transfer iptek dan luaran dari kegiatan ini tertera pada Tabel 2 berikut:

Tabel 2. Bidang, Masalah, Transfer Iptek dan Luaran

\begin{tabular}{|c|c|c|c|}
\hline Bidang & Masalah & Transfer IPTEK & Luaran \\
\hline \multirow[t]{3}{*}{$\begin{array}{l}\text { Penguatan SDM } \\
\text { (Kebersihan) }\end{array}$} & $\begin{array}{l}\text { Selama Pandemi } \\
\text { perangkat yang } \\
\text { ada dalam Masjid } \\
\text { Jami' At-Taqwa } \\
\text { Onekore atau } \\
\text { Masjid Papel } \\
\text { belum pernah di } \\
\text { bersihkan }\end{array}$ &  &  \\
\hline & $\begin{array}{l}\text { Area Lingkungan } \\
\text { sekitar Masjid dan } \\
\text { Selokan belum } \\
\text { dibersihakan } \\
\end{array}$ & $\begin{array}{l}\text { - } \text { Cara membersihkan } \\
\text { pekarangan yang baik } \\
\text { ditengah pandemi }\end{array}$ & $\begin{array}{l}\text { - Terciptanya tempat } \\
\text { ibdaha yang bersih dan } \\
\text { nyaman ketika beribdah } \\
\text { di mulai }\end{array}$ \\
\hline & $\begin{array}{l}\text { Belum } \\
\text { diberlakukan } \\
\text { mencuci tangan } \\
\text { ketika masuk area } \\
\text { Masjid }\end{array}$ & $\begin{array}{l}\text { Persiapan secara Psikologis dan } \\
\text { pelatihan }\end{array}$ & $\begin{array}{llr}\text { - Tersedianya } & \text { tempat } \\
\text { mencuci tangan sebelum } \\
\text { memasuiki area masjid } \\
\text { - Tersedianya } \\
\text { antiseptik di tempabun } \\
\text { pencucian tangan }\end{array}$ \\
\hline \multirow[t]{2}{*}{$\begin{array}{l}\text { Pendidikan } \\
\text { (Mengenai Covid } \\
\text { 19) }\end{array}$} & $\begin{array}{l}\text { Belum pernah } \\
\text { mendapatkan } \\
\text { pengetahuan } \\
\text { tentang bagaimana } \\
\text { menjaga jarak } \\
\text { dalam melakukan } \\
\text { ibadah }\end{array}$ & $\begin{array}{l}\text { Memberikan Pengetahuan } \\
\text { Mengenai Pentingnya Menjaga } \\
\text { Jarak dimasa Covid ini }\end{array}$ & $\begin{array}{l}\text { Meningkatnya pengetahuan } \\
\text { mengenai Covid } 19\end{array}$ \\
\hline & $\begin{array}{l}\text { Belum di buatnya } \\
\text { batas-batas dalam } \\
\text { Masjid untuk } \\
\text { melaksanakan } \\
\text { ibadah }\end{array}$ & Pembuatan jarak & $\begin{array}{l}\text { Penandaan jarak antara } 1 \\
\text { dengan lainnya }\end{array}$ \\
\hline
\end{tabular}




\section{HASIL DAN PEMBAHASAN}

Kegiatan pengabdian kepada Masyarakat dalam rangka Panca Windu ke 40 tahun Universitas Flores dilakukan di beberapa tempat ibadah di Kota Ende, yakni Masjid, gereja dan Pura. Tim Pengabdian kepada masyarakt kelompok kami mendapatkan tempat pengabdian sesuai hasil survey yaitu Masjid Jami' At-Taqwa Onekore atau Masjid Papel. Jama'ah yang berada di seputaran lokasi Masjid At-Taqwa Onekore sangat antusias dalam menyambut tim kerja Universitas Flores. Hal ini dibuktikan dengan penyambutan oleh Ketua Takmir Masjid dan warga masyarakat di sekitar Masjid.

Ketercapaian tujuan kegiatan secara umum sudah baik, Jika dilihat dari hasil kegiatan pembersihan dan penyemprotan disenfektan maka dapat disimpulkan bahwa tujuan kegiatan Bakti Sosial dapat tercapai. Kegiatan bakti sosial ini juga dilakukan untuk tujuan solidaritas dan mengandung unsur kebersamaan. Kegiatan pengabdian ini juga sejalan dengan kegiatan yang pernah dilakukan oleh Kinasih \& Dahliyana, (2018:26) dengan judul Pengabdian Membangun Solidaritas Peserta Didik Melalui Kegiatan Bakti Sosial Organisasi Siswa Intra Sekolah mempunyai tujuan untuk mengetahui bagaimana peran sekolah dan organisasi di dalamnya termasuk Organisasi Sosial Intra Sekolah (OSIS) dalam menanamkan nilai-nilai solidaritas sosial kepada anggotanya melalui kegiatan bakti sosial yang dilakukan oleh OSIS di SMAN 5 Cimahi. mampu membangun solidaritas sosial antar siswa, terlihat dari kegiatan bakti sosial tersebut mengandung unsur kebersamaan.

\section{Tema dan Bentuk Kegiatan.}

Kegiatan yang dilakukan ini memiliki tema "Panca Windu Uniflor ke 40 dengan Kerja Bakti".

\section{Tempat dan Waktu Kegiatan}

Kegiatan Pengabdian dengan bentuk Kerja Bakti dilaksanakan di Masjid Jami' At-Taqwa Onekore, jalan Wirajaya Kelurahan Onekore Kecamatan Ende Tengah, Kabupaten Ende. Kegiatan Bakti Sosial dilaksanakan pada hari Senin tanggal 20 Juli 2020. Dimulai pada pukul 06.30 WITA hingga selesai

\section{Peserta dan Penyelenggara Kegiatan}

Peserta merupakan jamaah Masjid Jami' At-Taqwa Onekore, sedangkan panitia penyelenggaranya merupakan Panitia 40 tahun Uniflor dan Dosen Fakultas Keguruan dan Ilmu Pendidikan yaitu Dosen Pendidikan MAtematika dan Dosen Pendidikan Sejarah.

\section{Gambaran Proses Kegiatan}

Kegitan dilaksanakan pada hari Senin tanggal 20 Juli 2020, dimulai pada pukul 06.30 WITA. Kegiatan dimuali dengan pembukaan oleh Ketua Panitian Panca Windu Uniflor dan sambutan oleh imam Takmir Masjid Onekore. Setelah pembukaan dan sambutan, kegiatan selanjutnya yaitu Pembersihan Selokan di Area Lingkungan Masjid Jami' At-Taqwa Onekore atau Masjid Papel







Gambar 2. Pembersihan Area Lingkungan Masjid Jami’ At-Taqwa Onekore atau Masjid Papel

Kegiatan dilanjutkan dengan pembersihan lingkungan dan teras Masjid. Serta penyediaan tempat ember dan sabun cuci tangan sebelum masuk ke dalam Masjid.


Gambar 3. Peyediaan Tempat dan Pembersihan Area Mencuci tangan.

Setelah kegiatan pembersihan area luar masjid selesai, maka kegiatan selanjutnya di lakukan di dalam masjid yaitu pembuatan tanda jarak, pengepelan dalam lantai masjid dan penyemprotan desinfektan.
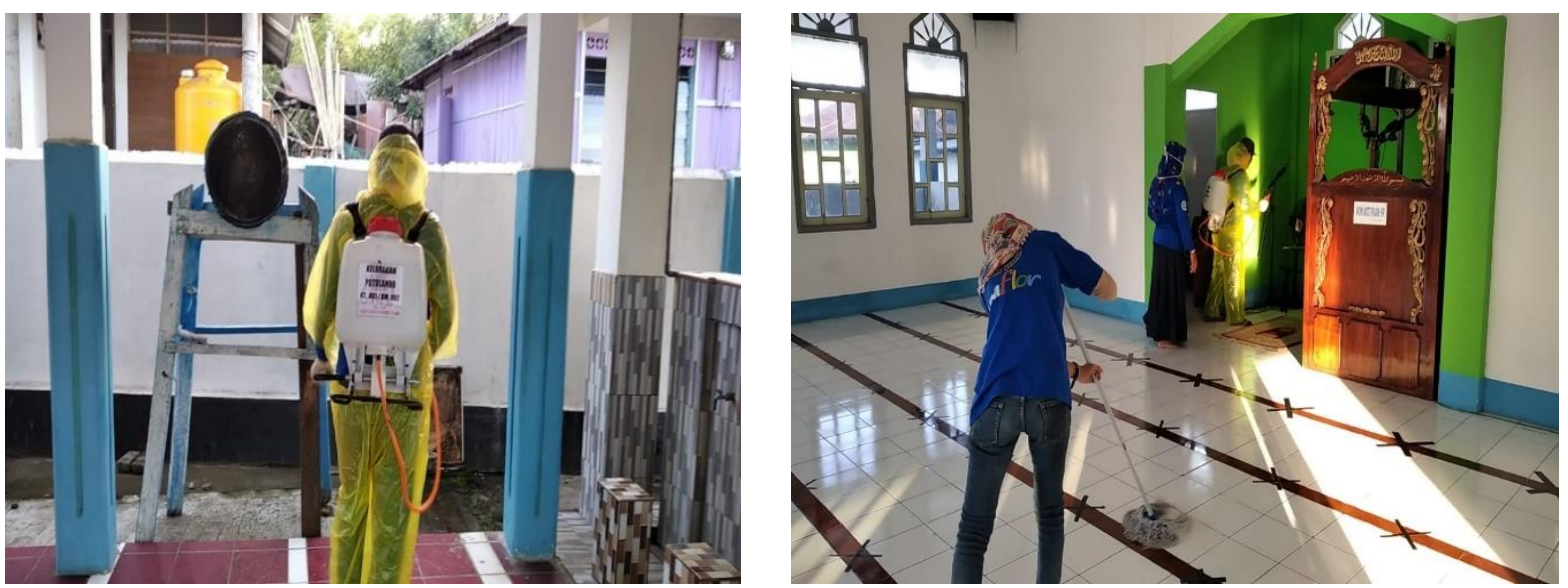

Gambar 4. Penyemprotan Desinfektan dan pembersihan serta pembuatan Batas (jarak) di dalam masjid 
Setelah semua selesai, kegiatan selanjutnya adalah pembersihan area tempat wudhu dan toilet Masjid. Semua dilakukan agar saat beribadah sudah dapat dilaksanakan, dapat terlaksana dengan aman, nyaman dan tentram.


Gambar 5. Pembersihan Area Toilet

Bersamaan dengan kegiatan Bakti Sosial, tim kerja juga menyerahkan tong sampah bantuan dari panitia Panca Windu Uniflor ke 40. Bantuan dimaksudkan untuk turut menjaga kebersihan di sekitar lingkungan Masjid At-Taqwa Onekore.



Gambar 6. Penyerahan Tempat sampah Kepada Takmir Masjid

\section{SIMPULAN DAN TINDAK LANJUT}

Kegiatan Bakti Sosial pembersihan lingkungan Masjid Jami' At-Taqwa Onekore dapat berjalan dengan baik sesuai dengan rencana kegiatan, yakni pembersihan lingkungan Masjid, pembersihan selokan irigasi, pengangkutan sampah dan penyemprotan disenfektan. Kegiatan Bakti Sosial mendapat sambutan yang sangat baik oleh masyarakat dan pengurus Masjid. 
Kesimpulan yang dapat diuraikan dari pelaksanaan kegiatan pengabdian ini sebagai berikut:

(a) Semua warga menjadi peserta pelatihan antusias dan memiliki komitmen yang baik untuk semua program yang telah didistkusikan sebelum kegiatan demi terwujudnya rasa aman dan tentram dalam beribadah di tengah pandemic Covid 19

(b) Telah ada peningkatan pemahan mengenai pengetahuan wabah Covid 19 dan bagaimana menjaga kemanan diri dalam meminimalisir terjangkitnya. Yakni dengan cara 3M (Menjaga Jarak, Mencuci Tangan dan Memakai Masker)

(c) Tempat ibadah yang bersih, aman dan Nyaman serta memiliki tanda batas jarak yang mana dalam beribadah.

\section{UCAPAN TERIMA KASIH}

Penghargaan setingi-tingginya kepada Tim Baktı Sosıal Pembersıhan Lingkungan Masjıd Jamı' At-Taqwa Onekore dalam rangka Panca Windu Unıversitas Flores ke-40 Tahun 2020 antara lain: Sofia Sa'o, Stefanus Notan Tupen, Loduvikus Carvallo, Ningsih, Finsensius Y.Naja, Agustina Mei, Vivien Restianim, Maria Trisna S.Wondo, Maria Fatima Mei, Natalia Peni, Maria G,D. Bantas, Yasinta Yenita Dhiki, Gregorius Taga, Hilaria Melania Mbagho, Stefania B.Seto, Juwita Merdja, Syaiful Amri, Damianus Tola, Yosef M. Banda, Helena R. Parera, F.Korosando dan Lely Suriyani.

\section{DAFTAR PUSTAKA}

Agustina, E., Rohmah, A., \& Kuspiyah, H. (2019). Pendampingan Bimbingan Belajar Bahasa Inggris dan Bakti Sosial di Yayasan Pendidikan dan Sosial Roudlotut Thullab. Jurnal Indonesia Mengabdi, $1(1), \quad 1-5$. http://journal.stkipnurulhuda.ac.id/index.php/IIMi/article/view/415

Ayub, Mohammad E. (1996) Manajemen Masjid Petunjuk Praktis bagi Para Pengurus. Jakarta: Gema Insani

Fauzzia, W., dkk. 2018. Pengabdian Kepada Masyarakat Bakti Sosial Bersama Jamaah Masjid Fatmah Hidayah. JURNAL ABDIMAS BSI: Jurnal Pengabdian Kepada Masyarakat. 1(1), 8186. DOI: https://doi.org/10.31294/jabdimas.v1i1.3076

Hidayatullah, F. 2010. Pendidikan Karakter: Membangun Peradaban Bangsa. Surakarta: Yuma Pustaka.

Kinasih, K. P. \& Dahliyana, A. 2018. Membangun Solidaritas Peserta Didik Melalui Kegiatan Bakti Sosal Organisasi Siswa Intra Sekolah. JURNAL SOSIORELIGI. 6(1) 22-28. https://ejournal.upi.edu/index.php/SosioReligi/article/view/10687

Kinasih, Kania Puspa (2017) MEMBANGUN SOLIDARITAS SOSIAL SISWA MELALUI KEGIATAN BAKTI SOSIAL OSIS: Studi Deskriptif Analitis SMAN 5 Cimahi. Skripsi tidak di publikasikan: Universitas Pendidikan Indonesia.

Mappaware, N. A., dkk. 2020. Bakti Sosialdi Lembang Marinding dan Kelurahan Lemo, Kecamatan Mengkendek, Tana Toraja. Jurnal Pengabdian Kedokteran Indonesia. 1(1),7-9

Qardhawi, Yusuf. (2000). Tuntunan Membangun Masjid. Jakarta: Gema Insani

Sarwono, Ahmad. (2001). Masjid Jantung Masyarakat: Rahasia Dan Manfaat Memakmurkan Masjid. Jakarta: Wihdah Press 
https://www.dream.co.id/sim/nusa-tenggara-timur/kab-ende/index2.html (diakses pada tanggal 25 Juli 2020 pukul 10.06 pm)

https://news.detik.com/berita/d-4846639/kebersihan-itu-bagian-dari-iman-ini-haditshaditsnya (diakses pada tanggal 25 Juli 2020 pukul 10.10 pm)

http://staffnew.uny.ac.id/upload/132309679/pengabdian/lampiran-cum-c-upload-1.pdf (diakses pada tanggal 25 Juli 2020 pukul $10.12 \mathrm{pm}$ ) 